\title{
Bisnis UKM Jamu Raden Sri Rastra Di Masa Pandemi Covid-19
}

\author{
Susilawati ${ }^{1}$, Hikmatulloh ${ }^{2}$ \\ ${ }^{1}$ Universitas Bina Sarana Informatika \\ e-mail: susilawati.ssl@bsi.ac.id

\begin{abstract}
${ }^{2}$ Sekolah Tinggi Manajemen Informatika dan Komputer Nusa Mandiri
\end{abstract} \\ e-mail: hikmatulloh.hkı@nusamandiri.ac.id
}

\begin{abstract}
Abstrak
Semakin meningkatnya kasus baru covid-19 khususnya di Indonesia, membuat setiap elemen di suatu negara bahkan kalangan masyarakat ikut berbondong-bondong melakukan langkah preventif demi terhindar dari virus corona atau COVID-19. Masa pandemi yang dialami juga membuat laju ekonomi terhambat, terdapat beberapa jenis bisnis yang relatif bertahan dan mampu tumbuh dalam kondisi pandemic covid-19 seperti UKM yang mengalihkan produksi ke produk kesehatan, salah satunya adalah UKM jamu, tidak sedikit yang membuka usaha jamu tradisional seperti Raden Sri Rastra, pemilik UKM jamu Raden di Sukabumi. Jamu merupakan salah satu minuman yang terdiri dari tanaman-tanaman obat yang kaya akan vitamin, mineral, dan zat-zat aktif yang memang memiliki khasiat sebagai antioksidan yang mampu meningkatkan daya tahan tubuh. Beragam minuman jamu tradisional yang diproduksi Jamu Raden mulai dari sereh jahe merah, kunyit asem segar, kunyit asam sirih, jahe rempah, beras kencur, cabe puyang dan bir peletok. UKM Jamu Raden memfokuskan usaha pada pembuatan minuman jamu tradisional karena produk ini jadi buruan orang dimasa pandemi. Selain manfaat untuk kesehatan tubuh bagi yang mengonsumsinya, juga ada nilai baik lain seperti memelihara warisan tradisional bangsa dan mendukung ekonomi di bidang pertanian, dan industri bangsa.
\end{abstract}

Kata Kunci: UKM, Jamu, Raden Sri Rastra.

\begin{abstract}
The increasing number of new cases of covid-19, especially in Indonesia, has made every element in a country even among the public flock to take preventive steps to avoid the corona virus or COVID-19. The pandemic period that was experienced also hampered the economic pace, there were several types of businesses that were relatively sustainable and able to grow in the conditions of the Covid-19 pandemic such as UKM that shifted production to health products, among which were the UKM Jamu, Not a few had opened traditional herbal medicine businesses such as Raden Sri Rastra, owner of UKM Raden herbal medicine in Sukabumi. Jamu is a drink consisting of medicinal plants which are rich in vitamins, minerals and active substances which have antioxidant properties that can increase endurance. A variety of traditional herbal drinks produced by Jamu Raden, ranging from sereh jahe merah, kunyit asem segar, kunyit asam sirih, jahe rempah, beras kencur, cabe puyang dan bir peletok. UKM Jamu Raden focuses its business on making traditional herbal drinks because this product is being hunted by people during the pandemic. Apart from the benefits for the health of the body for those who consume it, there are also other good values such as preserving the traditional heritage of our nation and supporting the economy in agriculture and our nation's industry.
\end{abstract}

Keywords: UKM, Jamu, Raden Sri Rastra

Diterima Februari 10, 2021; Revisi Februari 16 , 2021; Disetujui Maret 15, 2021 


\section{Pendahuluan}

Indonesia kini telah memasuki bulan kedelapan masa pandemi virus corona, sejak kasus pertama diumumkan pada awal Maret 2020. Pada Senin (2/11/2020), Satgas Covid-19 melaporkan adanya tambahan 2.618 kasus baru Covid-19. Dengan adanya tambahan kasus baru, per Senin (2/11/2020), Indonesia mencatatkan adanya 415.402 kasus infeksi virus corona. Dari jumlah tersebut, tercatat sebanyak 14.044 kasus berakhir dengan kematian dan 345.566 kasus dinyatakan sembuh. Pandemi virus corona (Covid-19) masih menghantui khususnya Indonesia. Sejak kasus pertama diumumkan, lonjakan pasien positif terus terjadi dan kian meningkat (Kompas.com, 2020).

Tingkat kecepatan dan ukuran skala cakupan penyebaran virus Covid-19 melebihi kasus wabah virus pada kejadian dekade sebelumnya (Maffioli, 2020). Covid19 menyebabkan respon masyarakat dunia sangat berbeda dengan kasus wabah virus yang pernah terjadi sebelumnya. Hal lain yang membedakan adalah status China yang menjadi titik awal sebaran Covid-19, merupakan Negara dengan kekuatan ekonomi nomor dua dunia sehingga berdampak luas pada interaksi bisnis dengan banyak negara mitra.

Penelitian Warwick McKibbin dan Roshen Fernando menunjukkan bahwa wabah Covid-19 dapat secara signifikan berdampak pada ekonomi global dalam jangka pendek (McKibbin \& Fernando, 2020). Skenario tersebut menunjukkan skala biaya yang mungkin dapat dihindari dengan investasi yang lebih besar dalam sistem kesehatan masyarakat di semua negara khususnya di negara-negara yang kurang berkembang dan yang populasi penduduk tinggi.

Mengonfirmasi kasus pertama infeksi virus corona penyebab Covid-19 pada awal Maret 2020. Sejak itu, berbagai upaya penanggulangan dilakukan pemerintah untuk meredam dampak dari pandemi Covid-19 di berbagai sektor. Hampir seluruh sektor terdampak, tak hanya kesehatan. Sektor ekonomi juga mengalami dampak serius akibat pandemi virus corona. Pembatasan aktivitas masyarakat berpengaruh pada aktivitas bisnis yang kemudian berimbas pada perekonomian. Laporan Badan Pusat Statistik (BPS) Agustus ini menyebut bahwa pertumbuhan ekonomi Indonesia pada kuartal II 2020 minus 5,32 persen. Sebelumnya, pada kuartal satu 2020, Badan Pusat Statistik melaporkan bahwa pertumbuhan ekonomi Indonesia hanya tumbuh sebesar 2,97 persen, turun jauh dari pertumbuhan sebesar 5,02 persen pada periode yang sama 2019 lalu

Pandemi virus Corona atau COVID-19 telah menimbulkan dampak yang sangat besar terhadap perekonomian. Bahkan perekonomian dunia nyaris jatuh dalam jurang resesi. Dua ratus lima belas negara menghadapi darurat kesehatan dan harus menyelamatkan warganya dari ancaman COVID-19, semua negara tengah berjuang untuk menyelamatkan diri dari tekanan ekonomi yang begitu dahsyat.

Dari sisi permintaan, suplai hingga produksi terkendala akibat virus ini. Pertumbuhan ekonomi dunia terkoreksi amat tajam dan berjuang agar tidak masuk ke jurang resesi, situasi seperti ini yang tengah dihadapi semua negara, termasuk negara Indonesia. Publik dunia tengah berbondong-bondong mengupayakan tindakan preventif demi menghadang virus corona COVID-19, khususnya di Indonesia, eksistensi jamu kembali naik ditengah rentetan cara menjaga daya tahan tubuh agar tak terdampak virus yang pertama terdeteksi di Wuhan, Tiongkok.

Di Indonesia, salah satu penopang pertumbuhan ekonomi terlihat dari kegiatan usaha kecil yang signifikan, baik di sektor tradisional maupun modern melalui Usaha Kecil dan Menengah (UKM). Menurut Kementerian PPN/Bappenas. Saat ini wabah virus yang bernama COVID- 19 telah mengganggu perekonomian secara global (McKibbin \& Fernando, 2020) dan berimbas ke Indonesia yang memengaruhi sektor ekonomi salah satunya pada UKM (Pakpahan, 2020). Menurut Organization for Economic Co-operation and Development (OECD) bahwa pandemi COVID-19 berdampak pada ancaman krisis ekonomi besar yang ditandai dengan berhentinya aktivitas produksi diberbagai negara, tingkat konsumsi masyarakat yang menurun, kepercayaan konsumen yang hilang, dan jatuhnya bursa saham yang akhirnya mengarah pada ketidak-pastian (OECD, 2020). Situasi pandemi COVID-19 memberikan tantangan dan peluang bagi Pemerintah Indonesia untuk menjaga keberadaan UKM. 
Terdapat beberapa jenis bisnis yang relatif bertahan dan mampu tumbuh dalam kondisi pandemic covid-19 seperti UKM yang mengalihkan produksi ke produk kesehatan seperti jamu hal tersebut dinilai sejalan dengan upaya meraih keunggulan bersaing melalui inovasi produk dan orientasi dinamika kebutuhan dan keinginan pasar (Alwi \& Handayani, 2018). Kesadaran masyarakat akan menjaga kesehatan dimasa pandemic ini maka penggunaan jamu sebagai alternatif pengobatan disamping obat modern pada masyarakat merupakan bagian dari indigenous knowledge masyarakat. Pemakaian jamu dan obat tradisional lainnya yang dilakukan secara turun temurun tidak terlepas dari peran orang tua dalam melestarikan budaya. salah satu cara menjaga kesehatan yang dilakukan masyarakat (terutama wanita) adalah dengan sering mengkonsumsi ramuan jamu yang harganya relatif murah Jamu memiliki beberapa keunggulan, seperti toksisitasnya rendah dan efek samping yang ditimbulkan ringan.

Faktor-faktor yang mempengaruhi konsumen membeli jamu meliputi faktor pribadi, faktor bauran pemasaran, faktor sosial, budaya, psikologi, dan faktor kesadran masyarakat untuk menjaga kesehatan.

Ketua Umum Perkumpulan Dokter Pengembang Obat Tradisional dan Jamu Indonesia (PDPOTJI) dr. Inggrid Tania menyebutkan bahwa Prof. Nidom memperkenalkan empon-empon atau rempah-rempah sebagai sumber senyawa aktif curcumin, berdasarkan penelitian non klinis Prof. Nidom pada kasus flu burung yang belum diuji coba pada manusia (Kaparino, 2020). Sedangkan untuk kasus COVID-19, belum ada penelitian spesifik tentang jamu, walaupun demikian, secara umum, jamu yang terdiri dari tanamantanaman obat kaya akan vitamin, mineral, dan zat-zat aktif memang memiliki khasiat sebagai antioksidan yang mampu mengaktifkan imunitas tubuh demi menangkal infeksi virus,berkhasiat sebagai anti-inflamasi yang dapat mencegah kerusakan atau peradangan sel akibat penyakit infeksi virus, juga, akan membantu mengatasi gejala batuk, pilek, meriang atau demam, sesak nafas, sakit kepala, lemas, dan mual yang sering meyertai penyakit infeksi virus, serta mempercepat proses pemulihan, walau belum dapat dinyatakan secara tegas karena belum ada pengujian klinis pada manusia untuk kasus spesifik COVID-19.

hasil penelitian selama ini menunjukkan bahwa herbal-herbal yang mengandung bahan aktif Curcumin, Resveratrol, Quercetin, Rhamnetin, Epigallocatechine, Phyllantin, dan Kaempferin memiliki aktivitas sebagai immunomodulator. Zat-zat yang tersebut terkandung dalam sederet bahan alami, seperti kunyit, temulawak, jahe, sereh, kencur, buah anggur, buah jambu biji, meniran, daun kelor, dan teh hijau. Jamu dapat dijadikan fondasi untuk menjaga tubuh dari penyakit asalkan dikonsumsi secara rutin".

Dimasa pandemic ini penjualan jamu tengah naik, dan banyak yang merasakan betapa segarnya jamu dengan ragam manfaat yang diracik menggunakan resep yang menyentuh indra perasa seseorang, jamu tak hanya dikonsumsi ditengah risiko infeksi corona, karena sangat penting setiap saat memelihara kesehatan, menjaga vitalitas, menjaga imunitas, dan mencegah penyakit dengan cara mengkonsumsi makanan, minuman, bahanbahan alam yang bermanfaat, misalnya jamu, Selain kita mendapatkan manfaatnya, juga ada nilai positif seperti memelihara warisan pengetahuan kesehatan tradisional bangsa kita dan memajukan ekonomi pertanian, serta industri bangsa sendiri.

\section{Metode Penelitian}

Metode penelitian yang digunakan adalah metode kualitatif deskriptif berbasis data sekunder dari hasil riset dan referensi kepustakaan mengenai data dan informasi yang terkait dengan penelitian. Interval waktu kajian kasus pada bulan September sampai pertengahan November 2020. Penelitian Entitas bisnis dibatasi di UKM produsen jamu RADEN, daerah Sukabumi Jawabarat, karena hanya produsen jamu inilah yang mau terbuka memberikan keterangan.

Teknik pengumpulan data menggunakan teknik dokumentasi sebagai suatu cara yang dilakukan peneliti untuk mengumpulkan data dari berbagai sumber referensi. Jenis data berupa data sekunder baik berupa data kualitatif maupun kuantitatif dari jurnal dan pemberitaan online. Data sekunder adalah data yang mengacu pada informasi yang dikumpulkan dari sumber yang telah ada. Sumber data 
sekunder adalah catatan atau dokumentasi perusahaan, dokumentasi pemerintah atau publikasi pemerintah, analisis industri oleh media, situs web dan lainnya (Sekaran, 2011).

Kebijakan dan upaya pencegahan skala sebaran Covid-19 yang pertama kali diumumkan oleh Presiden Joko Widodo, 2 Maret 2020, telah berimbas pada perubahan cara dan ritme beragam aktivitas, baik sosial kemasyarakatn, pelayanan public maupun kegiatan bisnis, yang menyebankan banyak UKM yang gulung tikar, Dampak covid tak selalu menyebabkan penjualan produk menyusut. produk usaha kecil menengah seperti jamu herbal malah laris manis. sejak wabah ini merebak omset salah satu produsen jamu meningkat hingga 50 persen, oleh sebab itu penulis mengambil judul "DAMPAK PANDEMI COVID-19 TERHADAP BISNIS UKM JAMU DIKOTA SUKABUMI"sebagai bahan penelitian dan kajian.

\section{Hasil dan Pembahasan \\ 3.1. Hasil Penelitian}

Data yang dirilis oleh website corona.help.com dan website worddometer.com per 3 April 2020, menunjukkan bahwa Indonesia berada pada urutan pertama diantara negaranegara ASEAN, berdasarkan dari total angka akumulasi kematian akibat Covid-19 (kemkes, 2020). Jumlah kasus Covid-19 di Indonesia saat ini tercatat 349.160 kasus,Sementara itu, jumlah kematian karena Covid-19 Indonesia. Total kematian yang tercatat di Indonesia adalah 12.268 jiwa (Kompas.com, 2020a).

Seruan dan kebijakan Pemerintah secara bertahap mempengaruhi ritme dan rutinitas yang berlangsung seperti biasanya. Sentra sentra perbelanjaan menurunkan aktivitasnya, destinasi wisata meliburkan layanannya, hal tersebut tentu sangat mempengaruhi laju ekonomi yang semakin terasa sulit. Terdapat beberapa jenis bisnis yang relatif bertahan dan mampu tumbuh dalam kondisi pandemic covid-19 seperti UKM yang mengalihkan produksi keproduk kesehatan, salah satunya adalah UKM Jamu, karena semakin besar kesadaran masyarakat untuk menjaga kesehatan, selain menerapkan protokol kesehatan dan berolahraga mereka juga sering mengkonsumsi obat atau suplemen yang dapat menjaga dan mempertahankan kesehatan, salah satunya dengan meminum ramuan atau jamu, sehingga UKM Jamu mampu menjalankan industri ditengah pandemi seperti ini.

\subsection{Pembahasan}

Covid-19 sebagai salah satu kejadian yang keberadaannya berada di lingkungan eksternal (external environment) relatif tidak terkontrol (uncontrollable) atau diluar kendali perusahaan. Berdasarkan data sekunder yang diperoleh dalam kurun waktu penelitian terlihat bahwa Covid 19 berdampak pada lingkungan internal (internal environment) entitas bisnis.

Sejak dulu Indonesia sudah dikenal sebagai Negara yang dianugerahi dengan kekayaan alam yang melimpah disertai dengan kesuburan lahan. Salah satu kekayaan alam yang dimiliki adalah tingginya biodiversitas termasuk tanaman obat-obatan sebagai bahan baku jamu.

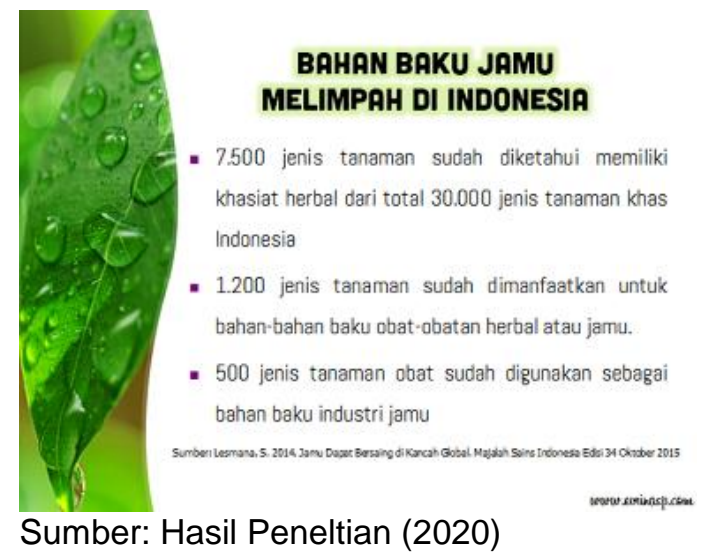

Gambar 1. Bahan Baku Jamu di Indonesia

Jamu merupakan ramuan tradisional sebagai salah satu upaya pengobatan yang telah dikenal luas dan dimanfaatkan oleh masyarakat dengan tujuan mengobati penyakit ringan, mencegah datangnya penyakit, menjaga ketahanan dan kesehatan tubuh. Pengobatan tradisisionil ini pada umumnya diyakini lebih aman daripada pengobatan modern, karena pengobatan tradisional tidak begitu keras juga lebih murah Sehingga daya beli masyarakat terhadap jamu cenderug menigkat. 


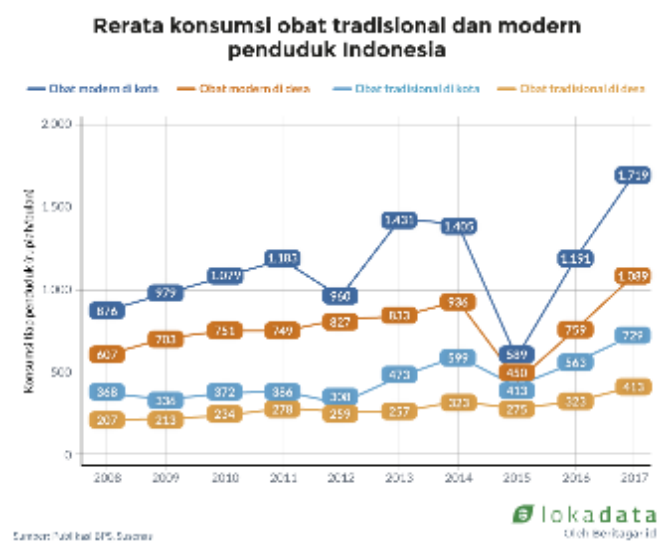

Sumber: Hasil peneltian (2020)

Gambar 2. Rerata Konsumsi Obat Tradisional dan Modern

Dampak covid justru menjadi peluang bagi UKM Jamu, Saat banyak bisnis lain berguguran akibat pandemi Covid-19, usaha jamu tradisional makin eksis. Tak sedikit yang membuka usaha jamu tradisional seperti Raden Sri Rastra, pemilik pemilik UKM jamu Raden di Sukabumi.

Memulai usaha pada Juli 2020 lalu, UKM Jamu Raden memfokuskan usaha pada pembuatan minuman jamu tradisional karena produk ini jadi buruan orang dimasa pandemi. Beragam minuman jamu tradisional yang diproduksi Jamu Raden mulai dari sereh jahe merah, kunyit asem segar, kunyit asam sirih, jahe rempah, beras kencur, cabe puyang dan bir peletok. semuanya memiliki kandungan dan manfaat masing-masing. Dari setiap jenis jamu herbal itu telah diramu untuk memberi dampak positif bagi tubuh. Jamu herbal berbahan dasar rempah-rempah seperti jahe, kunyit, temulawak yang diproduksinya laris diburu konsumen. Sejak bulan Maret ketika virus korona menyebar, penjualan jamu herbal meningkat karena jamu herbal berbahan dasar rempah-rempah ini diyakini banyak orang bisa meningkatkan daya tahan tubuh dari berbagai penyakit bukan hanya corona.

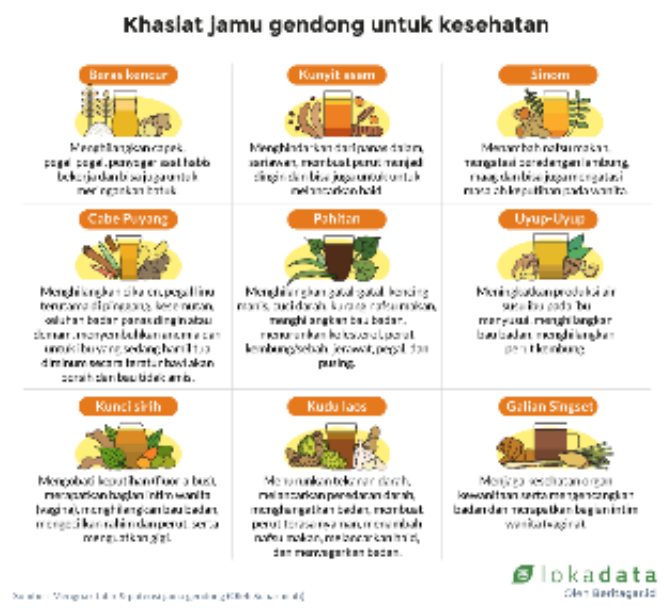

Sumber: Hasil peneltian (2020)

Gambar 3. Khasiat Jamu Gendong

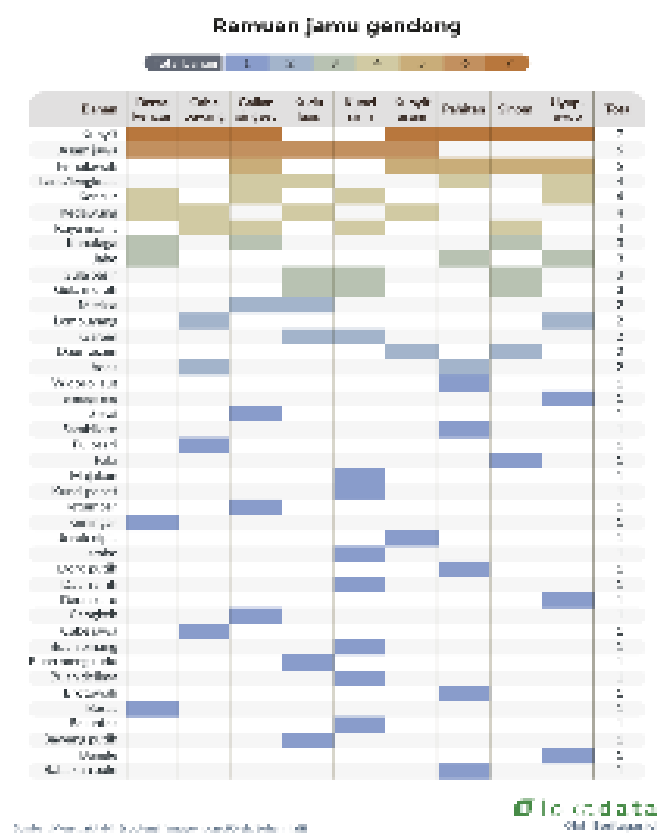

Sumber: Hasil Peneltian (2020)

\section{Gambar 4. Ramuan Jamu Gendong}

Harga jamu Raden berkisar Rp 10.000 sampai $\mathrm{Rp} 65.000$ per botol tergantung ukuran. UKM Jamu Raden sebulan sanggup menjual 550 botol sampai 600 botol, dengan omzet sekitar Rp 5.500.000 hingga Rp 6.000.000 juta. Jamu Raden mengandalkan penjualan secara online, baik lewat media sosial ataupun melalui marketplace semacam Tokopedia dan GoFood, juga tetap melayani penjualan secara offline. 
Salah satu faktor yang membuat produknya cepat mendapat pasar adalah karena Jamu Raden menjaga kualitas bahan dan pembuatannya secara tradisional. Misalnya memakai panci stainless steel untuk menjaga kebersihan dari produknya. Dengan strategi tersebut, Jamu Raden optimistis bisnisnya akan terus berjalan, bahkan setelah pandemi berakhir dan berharap, terjadi lonjakan pertumbuhan penjualan dimasa depan.

\section{Kesimpulan}

1. Kejadian Pandemi Covid-19 yang merupakan bencana non alam (nonnature disaster) menjadi salah satufaktor dari lingkungan luar (externalenvironment) yang memberikan dampak penurunan aktivitas bisnis, namun bisa mengungkit kegiatan bisnis yang inovatif mengalihkan produksi keproduk kesehatan seperti jamu

2. Kesadaran masyarakat akan menjaga kesehatan dimasa pandemic ini maka penggunaan jamu sebagai alternatif pengobatan disamping obat modern pada masyarakat merupakan bagian dari indigenous knowledge masyarakat

3. Kegiatan bisnis UKM yang masih bisa bertahan, berkembang dan tetap eksis pada masa pandemic adalah produk kesehatan melalui penyesuaian salah satunya adalah jamu tradisional.

\section{Referensi}

Alwi, T., \& Handayani, E. (2018). Keunggulan Bersaing Ukm Yang Dipengaruhi Oleh Orientasi Pasar Dan Inovasi Produk. Jurnal Pengembangan Wiraswasta, 20(3), 193.

https://doi.org/10.33370/jpw.v20i3.2 56

Kaparino, Y. (2020). Dr. Inggrid Tania: Jamu Temulawak Dan Kunyit Bermanfaat Hadapi Covid-19. Retrieved from https://kesehatan.rmol.id/read/2020 /03/19/426109/dr-inggrid-taniajamu-temulawak-dan-kunyitbermanfaat-hadapi-covid-19

kemkes. (2020). website corona. Retrieved from worddometer.com

Kompas.com. (2020). Perjalanan 8 Bulan Pandemi Virus Corona di Indonesia. Retrieved from https://www.kompas.com/tren/read/ 2020/11/02/180600865/perjalanan8-bulan-pandemi-virus-corona-diindonesia?page $=$ all

Maffioli, E. M. (2020). Perspective piece: How is the world responding to the novel coronavirus disease (COVID19) compared with the 2014 west African Ebola Epidemic? The importance of China as a player in the Global Economy. American Journal of Tropical Medicine and Hygiene, 102(5), 924-925. https://doi.org/10.4269/ajtmh.200135

McKibbin, W., \& Fernando, R. (2020). The Global Macroeconomic Impacts of COVID-19: Seven Scenarios. Asian Economic Papers, 1-55. https://doi.org/10.1162/asep_a_007 96

Pakpahan, A. K. (2020). Covid-19 Dan Implikasi Bagi Usaha Mikro, Kecil, Dan Menengah. Jurnal IImiah Hubungan Internasional, 0(0), 5964.

https://doi.org/10.26593/jihi.v0i0.38 70.59-64

Sekaran, U. (2011). Research Methods For Business (Metode Penelitian Untuk Bisnis). 